\title{
Identification and preliminary characterization of a sperm-binding protein in normal human semen
}

\author{
P. Abrescia, G. Lombardi*, M. De Rosa*, L. Quagliozzi*, J. Guardiola \\ and S. Metaforał
}

Institute of General Physiology, Faculty of Sciences, University of Naples, Naples ; ${ }^{*}$ Institute of Endocrinology, 2nd School of Medicine, University of Naples, Naples; $† C N R$ International Institute of Genetics and Biophysics, 80125 Naples, and $¥ C N R$ Institute of Molecular Embryology, 80072 Arco Felice, Naples, Italy

\begin{abstract}
Summary. In the seminal plasma of normal men a protein, immunologically related to a major protein (RSV-IV) secreted from the rat seminal vesicle epithelium, was detected by competition with RSV-IV in a specific radioimmunoassay using a rabbit anti RSVIV antiserum. The protein was partly $(80 \%)$ purified by column chromatography; characterization by gel electrophoresis indicated that the protein is slightly basic and has a molecular weight of 140000 . The protein was present on the surface of human spermatozoa as well as in the ejaculates of azoospermic men and it is believed to be a sperm-binding protein.
\end{abstract}

\section{Introduction}

The morphology and vitality of human spermatozoa have been examined for the relationships between sperm number and fertilizing ability and for diagnostic purposes in general (Hein, Grayhack \& Goldberg, 1975; Grayhack, Wendel, Lee \& Oliver, 1977; de Cerezo \& Cerezo, 1977; Crabbe, 1977; Witkin, Higgins \& Bendich, 1978; Reddy, Stark \& Zaneveld, 1979). More recently attention has been focussed on human seminal plasma which has a complex protein composition and enzymic properties (Tauber, Zaneveld, Propping \& Schumacher, 1975; Choen, Pontes, McDonald \& Rose, 1977; Blake \& Sensabaugh, 1978; Vihko, Konturri \& Korhonen, 1978; Burgett \& Kwan, 1979; Lam, Yam, Wilbur, Taft \& Chin-Yang, 1979; Lukac \& Koren, 1979; Sutton, 1979; Perwein \& Schill, 1982 a, b; Bischof et al., 1983). Seminal proteins have been generally considered of great importance for survival of spermatozoa in the female reproductive tract and for maintenance of their fertility, even though definite experimental proof of this is still lacking. In particular a group of proteins (so called 'Sperm-coating antigens'), secreted from the male accessory sex organs, are of special interest in view of their ability to bind to the sperm surface, thereby conferring new antigenic properties to the sperm cell and suggesting an involvement in sperm capacitation-decapacitation processes.

In this paper we present data concerning the purification from normal human semen of a basic protein $\left(\mathrm{M}_{\mathrm{r}}\right.$ 140000) immunologically related to RSV-IV, a major protein secreted under transcriptional androgen control from the rat seminal vesicles epithelium (Ostrowski, Kistler \& Kistler, 1979; Mansson, Sugino \& Harris, 1981) and able to bind to the rat epididymal sperm surface (unpublished results from our laboratories).

\section{Materials and Methods}

Preparation and characterization of the semen samples. Normal and pathological semen samples were obtained by masturbation after 3 days of sexual abstinence from healthy, fertile volunteers $\left(\mathbb{N P}^{3}=9\right)^{9}$ 
and from azoospermic patients affected by idiopathic hypogonadotrophic hypogonadism $(\mathrm{N}=5)$. The samples were immediately diluted with one volume of an ice-cold dilution buffer containing $250 \mathrm{~mm}-\mathrm{NaCl}, 30 \mathrm{~mm}-\mathrm{KCl}, 2 \mathrm{mM}-\mathrm{MgCl}_{2}, 2 \mathrm{~mm}-\mathrm{EDTA}, 80 \mathrm{~mm}$-Tris- $\mathrm{HCl}$ (pH 8 ) and $6 \mathrm{~mm}$-phenylmethylsulphonyl fluoride (PMSF). After centrifugation $\left(25000 \mathrm{~g}, 20 \mathrm{~min}, 4^{\circ} \mathrm{C}\right)$ the supernatant was extensively dialysed at $4^{\circ} \mathrm{C}$ against a dialysis buffer $(150 \mathrm{~mm}-\mathrm{NaCl}, 20 \mathrm{~mm}-\mathrm{HCl}, \mathrm{pH} 8)$ containing $1 \mathrm{~mm}$-EDTA and 3 mM-PMSF to prevent proteolysis (Edwards, Tollaksen \& Anderson, 1981). The measured endocrine characteristics of the normal subjects $(\mathrm{N})$ and of the azoospermic patients (IHH) (19-25 years old), expressed as mean \pm standard deviation were as follows: $6.7 \pm 1.4(\mathrm{~N})$ and $2 \cdot 8 \pm 0.6(\mathrm{IHH}) \mathrm{mi} . \mathrm{u}$. FSH/ml $; 7 \cdot 0 \pm 1 \cdot 7(\mathrm{~N})$ and $2.6 \pm 0.8(\mathrm{IHH}) \mathrm{mi} . \mathrm{LH} / \mathrm{ml} ; 8 \cdot 3 \pm 3(\mathrm{~N})$ and $7 \cdot 5 \pm 2(\mathrm{IHH}) \mathrm{ng}$ prolactin $/ \mathrm{ml} ; 790 \pm 140(\mathrm{~N})$ and $31 \pm 17(\mathrm{IHH}) \mathrm{ng}$ testosterone $/ \mathrm{ml} ;$ and $44 \pm 15$ (N) and $25 \pm 9(\mathrm{IHH}) \mathrm{pg}$ oestradiol $/ \mathrm{ml}$. Sperm characteristics for normal subjects were as follows: $34.5 \times 10^{6} \pm 18 \times 10^{6}$ spermatozoa $/ \mathrm{ml} ; 70 \pm 6 \%$ motile spermatozoa as determined $1 \mathrm{~h}$ after ejaculation; and $65 \pm 9 \%$ motile spermatozoa with forward progression as determined $1 \mathrm{~h}$ after ejaculation. Plasma FSH and LH were evaluated by Kit-set RIA from Serono, Rome, Italy; plasma testosterone was evaluated by Kit-set RIA from Sorin, Saluggia, Italy.

The diagnosis of azoospermia was confirmed by evaluating basal concentrations of plasma FSH, LH and testosterone. Endocrine and skull X-ray examinations showed isolated gonadotrophin deficiency without signs of sellar or extrasellar masses. Anosmia was absent in all the patients, but some patients showed degrees of hyposmia.

Polyacrylamide slab gel electrophoresis ( $P A G E$ ). Appropriate amounts of proteins, measured according to Lowry, Rosebrough, Farr \& Randall (1951), were analysed by PAGE on slab gels $(20 \times 10 \times 0.15 \mathrm{~cm})$. For molecular weight measurements we used $15 \%$ acrylamide gels (acrylamide: $N, N^{\prime}$-methylenebisacrylamide $=15 \%: 0 \cdot 4 \%$ ) containing $6 \mathrm{M}$-urea and $0 \cdot 1 \%$ SDS with Tris-glycine ( $\mathrm{pH} \mathrm{8.3)}$ as running buffer (Laemmli, 1970). The protein samples, dissolved in 20-30 $\mu \mathrm{l}$ buffer (O'Farrell, 1975), were boiled for $3 \mathrm{~min}$ and then solid urea was added to give a final concentration of $6 \mathrm{M}$. PAGE fractionation of protein samples according to their charge density was performed in $6 \mathrm{M}$-urea- $5 \%$ acetic acid $\left(15 \%\right.$ acrylamide $+0 \cdot 13 \% \mathrm{~N}, \mathrm{~N}^{\prime}$-methylenebisacrylamide; running buffer: $5 \%$ acetic acid).

Radioimmunoassay of human sperm-binding protein. Rat seminal vesicle protein (RSV-IV), labelled with $\left[{ }^{35} \mathrm{~S}\right] \mathrm{methionine,} \mathrm{was} \mathrm{synthesized} \mathrm{in} \mathrm{vitro} \mathrm{in} \mathrm{precursor} \mathrm{forms} \mathrm{by} \mathrm{a} \mathrm{rabbit} \mathrm{cell-free}$ reticulocyte system as previously described (Abrescia, Guardiola, Felsani \& Metafora, 1982) and used as radioactive antigen in the assay.

The labelled protein was immunoprecipitated with an anti-RSV-IV specific rabbit antiserum (Abrescia et al., 1982). The presence of a sperm-binding protein in human seminal plasma samples was detected by its ability to displace labelled RSV-IV from the immunocomplex. Appropriate amounts of the pure native, unlabelled RSV-IV protein (Ostrowski et al., 1979) produced 100\% displacement of the RSV-IV protein synthesized in vitro. The protein contents of different seminal plasma samples were normalized so as to minimize any interference due to individual variations. The competition for the labelled antigen was performed by incubating for $60 \mathrm{~min}$ at room temperature 200000 c.p.m. of labelled RSV-IV with appropriate amounts of seminal plasma proteins in the presence of antiserum to RSV-IV $(3 \mu \mathrm{l})$ in a final volume of $400 \mu \mathrm{l}$ containing $1 \%$ Triton X-100, 1\% sodium deoxycholate, $20 \mathrm{~mm}$-Tris- $\mathrm{HCl}(\mathrm{pH} \mathrm{7.5),} 150 \mathrm{~mm}-\mathrm{NaCl}, 5 \mathrm{~mm}-\mathrm{EDTA}$, $3 \mathrm{mM}-\mathrm{PMSF}$ and $0.5 \mathrm{mg}$ bovine serum albumin $/ \mathrm{ml}$. The amount of antiserum to RSV-IV used was selected as that precipitating $50 \%$ of the specific radioactive antigen. Details of the experimental procedure to detect the labelled immunocomplex are reported elsewhere (Abrescia et al., 1982). In a control experiment it has been shown that an excess amount of human blood plasma proteins $(5 \mathrm{mg})$ does not displace radioactive RSV-IV from the immunocomplexes with the specific antibodies. By appropriate experiments we have ruled out the possibility that the non-ionic detergent concentrations used in the immunoassay can interfere with the immunocomplex formation. 


\section{Results}

\section{Detection of sperm-binding protein in normal human semen}

The liquid and cellular fractions of normal human semen were analysed for the presence of proteins homologous to RSV-IV. The results in P1. 1, Fig. 1 show that increasing amounts of seminal plasma antigens progressively displace the ratioactive antigen from the anti-RSV-IV antibodies. In particular, about $1 \mathrm{mg}$ total plasma proteins produced, under the experimental conditions used, a label displacement comparable to that of $20 \mu \mathrm{g}$ pure RSV-IV. On the basis of the cross reactivity of RSV-IV and sperm-binding protein (see below) we calculate that, in normal human seminal plasma, the sperm-binding protein represents $0.5 \%$ of the total proteins.

The same assay was used to investigate whether antigens related to the RSV-IV protein were present on the surface of the spermatozoa. Freshly ejaculated normal human spermatozoa $(25 \times$ $10^{6}$ ) were suspended in $5 \mathrm{ml}$ dilution buffer (see 'Methods') and washed in the same medium by successive centrifugations $(10 \mathrm{~min}$ at $500 \mathrm{~g}$ ) until the last supernatant was free of the sperm-binding protein as determined by radioimmunoassay. The final pellet was suspended in $300 \mu \mathrm{l}$ of sperm extraction buffer (150 mM-NaCl, 20 mM-Tris- $\mathrm{HCl}$, pH 7.5; 5 mM-EDTA, 3 mM-PMSF, $1 \%$ Triton $\mathrm{X}-100,1 \%$ sodium deoxycholate) and incubated at room temperature for $10 \mathrm{~min}$. After centrifugation $\left(20000 \mathrm{~g}, 4^{\circ} \mathrm{C}, 30 \mathrm{~min}\right), 100 \mu$ l supernatant were used for RIA. The results indicate that antigens extractable by non-ionic detergents from the sperm surface successfully compete for anti-RSV-IV antibodies with RSV-IV protein labelled in vitro. The sperm extract was able to displace $90 \%$ of the labelled RSV-IV protein in a competition radioimmunoassay: the displacement value obtained with unlabelled RSV-IV in the same assay conditions was $88 \%$.

\section{Purification of sperm-binding protein}

About $250 \mathrm{mg}$ protein from the dialysed seminal plasma of 9 normal ejaculates (see 'Methods') were loaded on a Sephacryl S-200 column $(0.9 \times 90 \mathrm{~cm})$ equilibrated and eluted with $0 \cdot 1 \mathrm{M}$-sodium acetate, pH 5.1, $5 \mathrm{~mm}-\beta$-mercaptoethanol, $1 \mathrm{~mm}-\mathrm{PMSF}$ and $1 \%$ trasylol (Buffer A). Fractions positive for the sperm-binding protein and containing high molecular weight proteins were pooled and represented $50-60 \%$ of the total proteins loaded (Pl. 1, Fig. 2). This material was then applied onto a CM-Sepharose CL-6B column $(0.9 \times 10 \mathrm{~cm})$ equilibrated in Buffer A. The column was washed until no absorbance at $280 \mathrm{~nm}$ was detectable in the eluate. Elution of the retained proteins was performed by a $\mathrm{NaCl}$ gradient $(0-250 \mathrm{~mm})$ in Buffer $A$. The fractions positive for the spermbinding protein were analysed by charge density on polyacrylamide gel in denaturing conditions and contained at least two basic protein components (Pl. 2, Fig. 3). These proteins, after precipitation in $100 \%$ ammonium sulphate, were dissolved in $50 \mu \mathrm{l} \mathrm{Buffer} \mathrm{A}$ and applied on a Sephadex G-200 column $(0.7 \times 20 \mathrm{~cm})$ equilibrated and eluted by the same buffer. The spermbinding protein was detected in the central peak of the elution pattern (Text-fig. 1) (apparent $\mathbf{M}_{\mathrm{r}}$ $140000 \pm 5000$ ). The same molecular weight has been found by SDS-PAGE analysis (data not shown). Purity of the protein was electrophoretically tested by denaturing PAGE in $5 \%$ acetic acid. The resulting pattern (Pl. 2, Fig. 4) showed only slight contamination by a few proteins endowed with higher cathodic mobilities. Densitometric analysis of this gel indicated that the sperm-binding protein isolated by the simple chromatographic techniques described above was about $80 \%$ pure. Therefore, from $1 \mathrm{~g}$ crude human seminal plasma proteins about $0.1 \mathrm{mg}$ partly purified spermbinding protein can be obtained (see Lowry et al., 1951). The protein fraction homologous to RSVIV protein thus represented about $0.01 \%$ of the total protein amount loaded, a value which is in good agreement with that estimated from immunological data. Isotopic dilution experiments, by using ${ }^{125} \mathrm{I}$-labelled RSV-IV and unlabelled purified sperm-binding protein or RSV-IV indicate that the two antigens share $70-80 \%$ of cross-reactivity (unpublished data). 


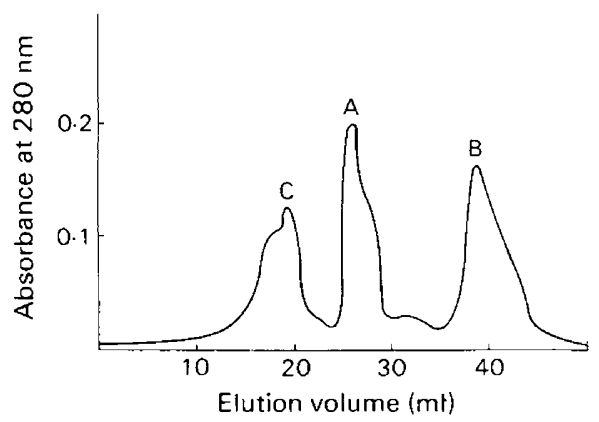

Text-fig. 1. G-200 Sephadex chromatogram of the RIA-positive normal seminal plasma proteins eluted from the CM-Sepharose CL-6B column. The fraction volume was $1 \mathrm{ml}$. The letters refer to molecular weight markers used to calibrate the gel filtration volumes $(C=$ catalase, $M_{r} 250000 ; A=$ aldolase, $M_{r} 161000 ; B=$ bovine serum albumin, $M_{r} 68000$ ).

\section{Origin of the sperm-binding protein}

The amounts of sperm-binding protein in the seminal plasma of azoospermic patients and healthy fertile men were compared. The seminal plasma samples were tested for absence of proteolytic activity by SDS-PAGE. The electrophoretic patterns of these samples showed well defined bands scattered over the migration profile (data not shown); no change was detectable in the protein pattern after incubation of seminal plasma for $2 \mathrm{~h}$ at $37^{\circ} \mathrm{C}$. This result suggests that proteolytic activity does not significantly affect such profiles, the major bands being located in the high molecular weight region. The amounts of displacing factors for RSV-IV protein present in the seminal plasma samples were measured by following the sequential fall of labelled protein bound to anti-RSV-IV antibodies (Text-fig. 2). The results indicate that the amount of sperm-binding protein present in $1 \mathrm{mg}$ proteins from the seminal plasma of normal and azoospermic men completely displaced the radioactive RSV-IV protein from its specific immunocomplex (P1. 2, Fig. 5 ), thus ruling out the spermatozoa as the source of the sperm-binding protein.

\section{PLATE 1}

Fig. 1. Homology between human sperm-binding protein and RSV-IV protein: SDS-urea PAGE analysis of $\left[{ }^{35}\right.$ S]methionine-labelled RSV-IV after immunoprecipitation with antiRSV-IV antibodies in the presence or absence of different amounts of human seminal plasma proteins. Lane I: $1 \times 10^{5}$ c.p.m. in-vitro labelled translation products of rat $11 \mathrm{~s} \mathrm{mRNA} \mathrm{(see}$ 'Methods'); Lane 2: as in Lane 1 after immunoprecipitation with anti-RSV-IV antibody; Lanes $3,4,5,6$ : as in Lane 2, but immunoprecipitated in the presence of $50,200,625$ and $2000 \mu \mathrm{g}$ human seminal plasma proteins, respectively. The gels were prepared for fluorography according to Bonner \& Laskey (1974).

Fig. 2. Seminal plasma proteins eluted from a Sephacryl S-200 column. The fraction volume was $1 \mathrm{ml}$. The inset refers to the SDS-urea $-15 \%$ PAGE analysis of the proteins present in the fractions corresponding to peaks a, b, c, d (Lanes 2, 3, 4, 5 respectively). Lane 1 gives the pattern of the total seminal plasma proteins. The molecular weight markers are $\beta$-galactosidase, $M_{r} 130000$; bovine serum albumin, $M_{r} 68000$; ovalbumin, $M_{r} 43000$; myoglobin, $M_{r} 17000$. All the material present in peak e had molecular weight lower than 2000-3000. The fractions positive for sperm-binding protein in the radioimmunoassay are indicated by the horizontal bar. 


\section{PLATE 1}

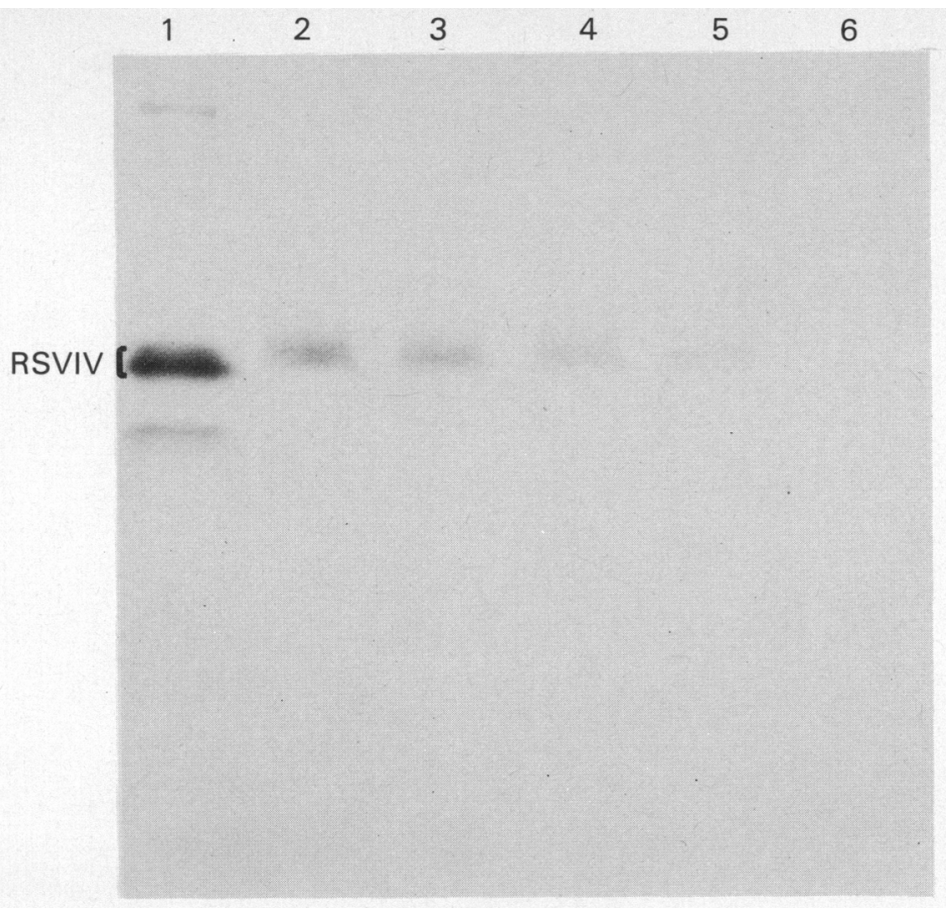

(1)

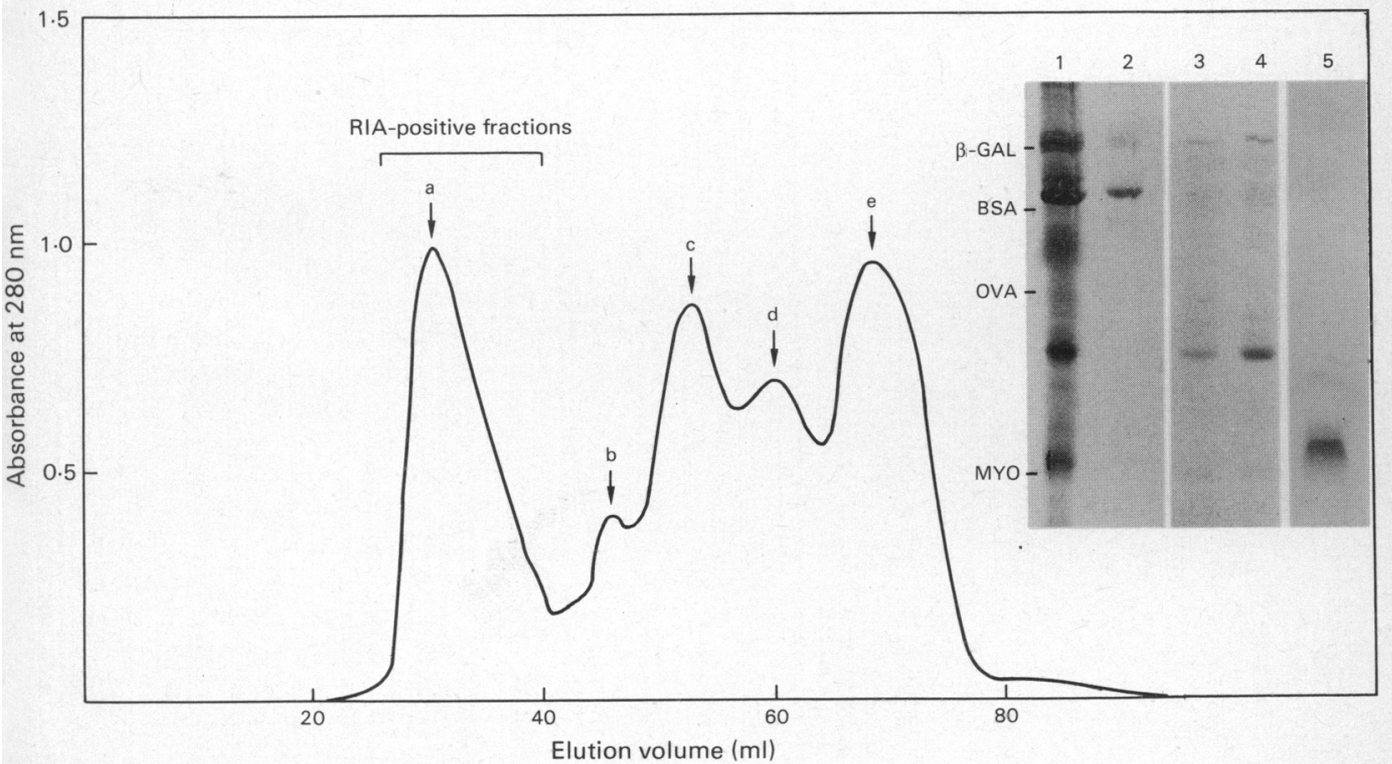

(Facing p. 74) 
PLATE 2

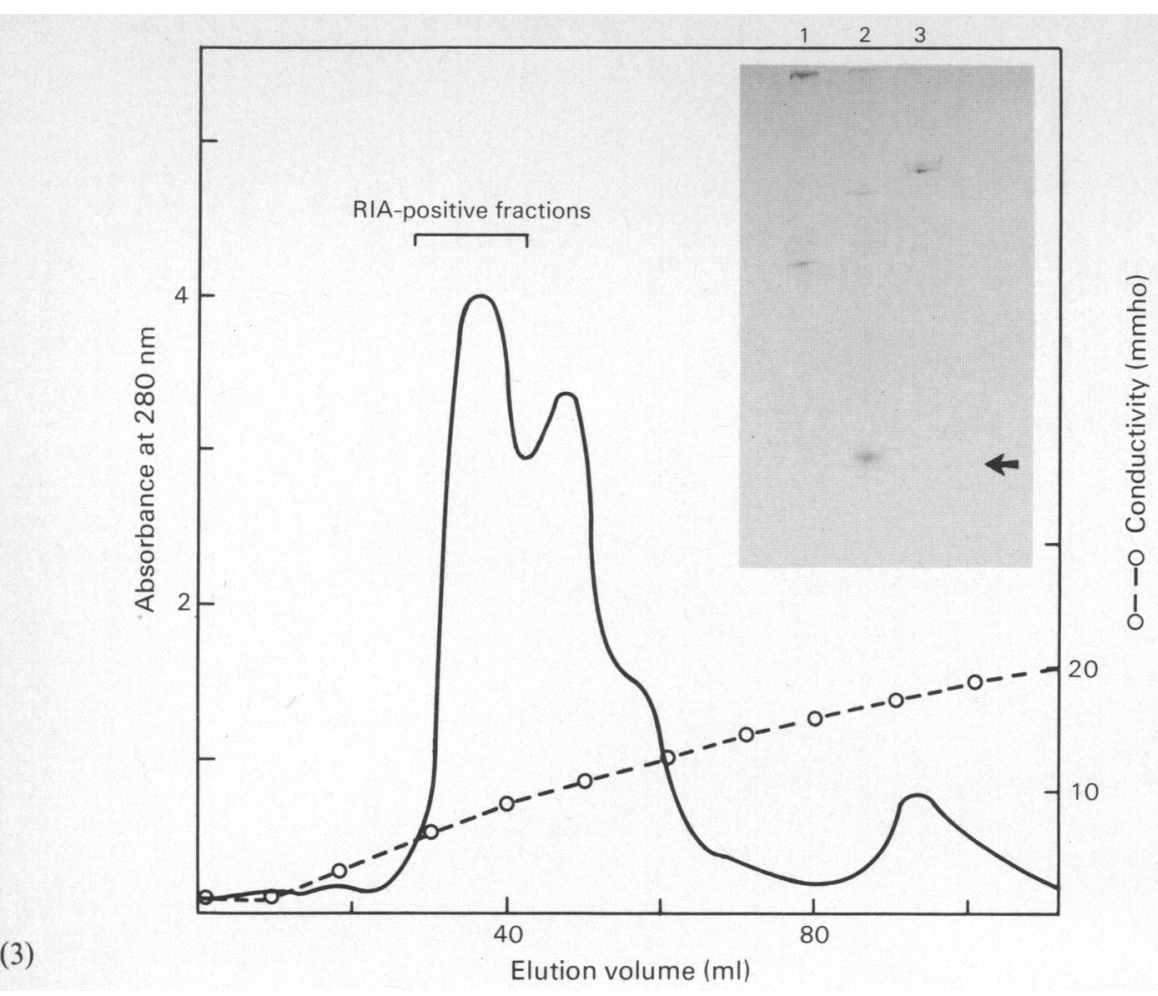

(3)
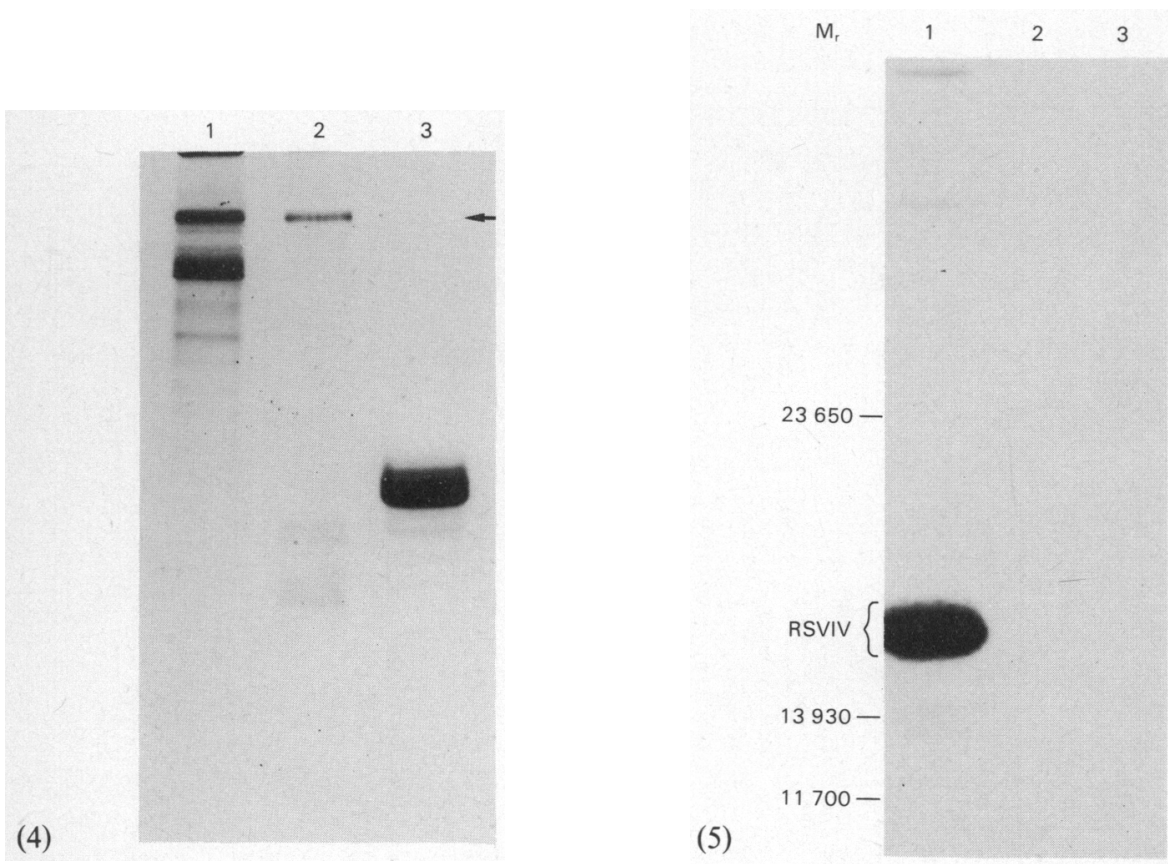


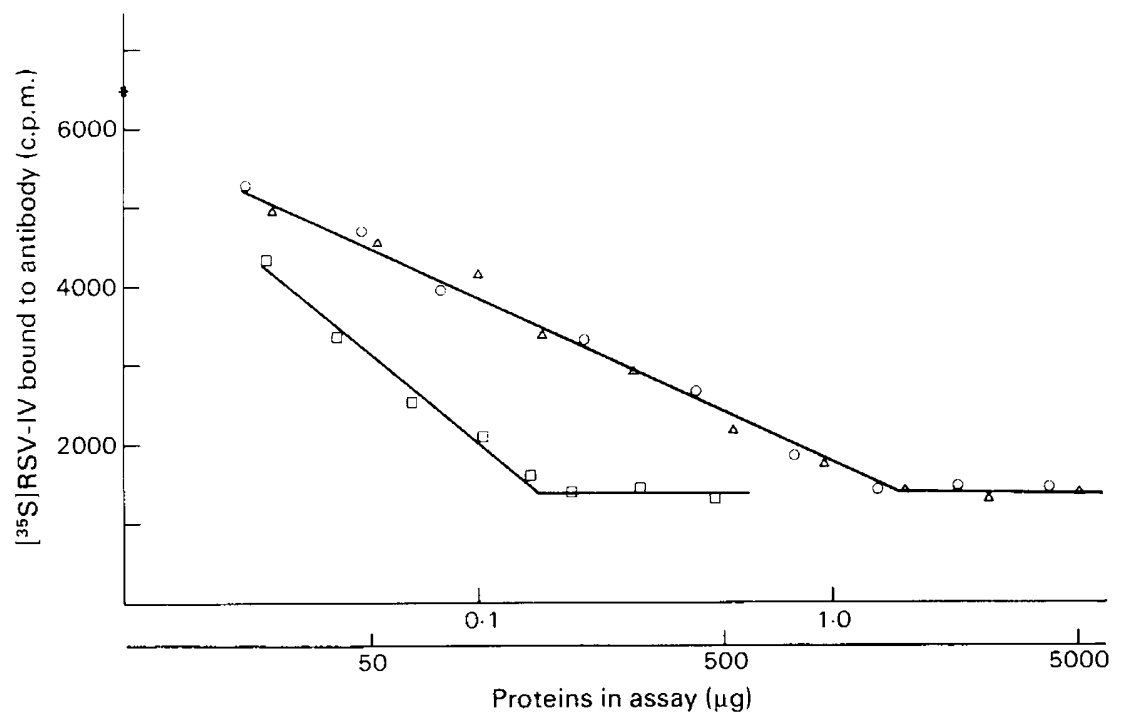

Text-fig. 2. Typical radioimmunoassay. $\left.{ }^{35} S\right]$ Methionine-labelled RSV-IV protein incubated alone $\left(^{*}\right)$; incubated with unlabelled RSV-IV $(\square-\square)$; incubated with human seminal plasma proteins from normal $\left(\mathrm{O}_{-} \mathrm{O}\right)$ or azoospermic $(\triangle-\triangle)$ men.

\section{Discussion}

This report describes the identification and the purification in human seminal plasma of a protein immunologically related to a major protein secreted from the rat seminal vesicle epithelium. A competition radioimmunoassay has been used as a rapid, sensitive and informative approach to the study of the sperm-binding protein.

\section{PLATE 2}

Fig. 3. Absorbance profile of the CM-Sepharose CL-6B chromatography of the RIA-positive normal seminal plasma proteins eluted from the Sephacryl S-200 column. The fraction volume was $1 \mathrm{ml}$. The inset refers to urea-PAGE analysis in $5 \%$ acetic acid of the proteins present in the fractions 35, 49 and 55 (Lanes 1,2 and 3 respectively). The arrow indicates an electrophoretic mobility of 0.25 as related to pyronine $\mathrm{Y}$ migration. The fractions positive for sperm-binding protein in the RIA are indicated by the horizontal bar.

Fig. 4. Urea-PAGE analysis in $5 \%$ acetic acid of the RIA-positive normal seminal plasma proteins present in the central peak of the Text-fig. 1 absorbance profile (Lane 2) compared with the basic proteins present in the loading of the CM-Sepharose CL-6B column (Lane 1). Native RSV-IV protein is present in lane 3. The arrow indicates the band corresponding to human sperm-binding protein $\left(\mu_{\mathrm{E}} \simeq 0 \cdot 15\right)$.

Fig. 5. SDS-urea-PAGE of ${ }^{35}$ S $]$ methionine labelled RSV-IV protein after immunoprecipitation with anti-RSV-IV antibodies in the presence or absence of human seminal plasma proteins. Lane 1: labelled RSV-IV, after immunoprecipitation; Lane 2: as in lane 1 but in the presence of $2 \mathrm{mg}$ normal human seminal plasma proteins during the immunoprecipitation; Lane 3: as in lane 1, but with $2 \mathrm{mg}$ seminal plasma proteins from azoospermic men during the immunoprecipitation. SDS-urea-PAGE analysis was performed on $15 \%$ polyacrylamide gels as described in Text-fig. 1. The molecular weight markers are: cytochrome $C\left(\mathbf{M}_{\mathrm{r}}=11700\right)$; lysozyme $\left(M_{r}=13930\right) ; \alpha$-chymotrypsinogen $\left(M_{r}=23650\right)$. 
The quantity of the sperm-binding protein in the seminal plasma of normal men and patients with idiopathic hypogonadotrophic hypogonadism (low testosterone) is the same, whereas RSV-IV seems to be secreted under transcriptional androgen control. If large amounts of the human protein were attached to the sperm surfaces, the azoospermic ejaculates would contain a much lower concentration of such an antigen. On the other hand, this protein might be present only in very small amounts on the spermatozoa, as compared to the concentration of the soluble form. In the latter circumstance the expression at the gene(s) coding for the sperm-binding protein should be very sensitive to low testosterone concentrations. The titration of the sperm-binding protein in the normal and azoospermic ejaculates and the study of the isolated specific gene characteristics will distinguish between these two possibilities. The data reported in this paper indicate that this protein is not present in the seminal plasma because it is derived from spermatozoa (see 'Results') but is most probably secreted by an accessory sexual gland since it has been detected in the ejaculates of azoospermic men. On the basis of the human-rat analogy for this system we suggest that the human seminal vesicle epithelium might be engaged in the active synthesis of the spermbinding protein.

The rat protein and its human counterpart have in common the ability to bind to spermatozoa, hence suggesting a functional homology. In comparison with the rat counterpart, however, human sperm-binding protein has a higher molecular weight $\left(M_{r} 140000\right.$ compared with 17000 in rat) and it is markedly less basic, as deduced from its behaviour in cationic exchange column chromatography and in denaturing PAGE in $5 \%$ acetic acid. These differences could be a consequence of evolutionary changes at the genomic level or of enzymic post-translational modifications such as polymerization processes by transglutaminases, phosphorylations or acetylations. The last possibility is supported by recent experiments (unpublished data from our laboratories) showing that: (1) the electrophoretic mobility of the RSV-IV protein, after incubation with the rat prostatic transglutaminase in the presence of calcium ions, is markedly decreased on SDS-PAGE; (2) a calcium-dependent transglutaminase is active in normal human seminal plasma; and (3) the RSVIV protein, after in-vitro phosphorylation, has a higher apparent molecular weight (about 70 000).

Sperm-coating antigens are thought to play a role in the sperm capacitation-decapacitation processes and in the mechanism which allows the spermatozoa to escape immunosurveillance by the female (Dravland \& Joshi, 1981; Mukherjee, Agrawal, Manjunath \& Mukherjee, 1983). The sperm-coating antigen characteristics of the human sperm-binding protein and the availability of a radioimmunoassay to detect low levels of this protein in the seminal plasma suggest some potential applications to fertility control and infertility. The immunological approach has been widely used in studies on fertility control (Gleicher, 1981). In addition, immunization of females by seminal plasma or spermatozoa has been shown to inhibit the fertilization process (McLaren, 1964). Administration of the sperm-binding protein to fertile women could produce an active immunization against spermatozoa, resulting in effective contraception. Moreover, should the fertilization efficiency of spermatozoa be dependent on the absence or low levels of this spermbinding protein, the titration of this antigen by radioimmunoassay would be very useful as a diagnostic tool for the detection of specific male infertilities.

We thank Professor Alberto Monroy for critical reading of the manuscript.

This research has been supported by CNR funds and a grant from Progetto Finalizzato 'Ingegneria Genetica e Basi Molecolari delle Malattie Ereditarie' of the CNR.

\section{References}

Abrescia, P., Guardiola, J., Felsani, A. \& Metafora, S. (1982) Expression in male and genomic organization of the gene(s) coding for a major protein secreted by the rat seminal epithelium. Nucleic Acid Res. 10, 1159-1174.

Bischof, P., Martin-Du-Pan, P., Lauber, K., Girard, J.P., 
Hermann, W.L. \& Sizonenko, P.C. (1983) Human seminal plasma contains a protein that shares physiochemical, immunochemical and immunosuppressive properties with pregnancy-associated plasma protein-A. J. clin. Endocr. Metab. 56, 359-362.

Blake, E.T. \& Sensabaugh, G.F. (1978) Genetic markers in human semen. II. Quantitation of polymorphic proteins. J. Forensic Sci. 23, 717-729.

Bonner, W.M. \& Laskey, R.A. (1974) A film detection method for tritium-labelled proteins and nucleic acids in polyacrylamide gels. Eur. J. Biochem. 46, 83 88.

Burgett, M.W. \& Kwan, S. (1979) Immunological characterization of the creatine kinase isoenzyme in human semen. Clin. Chem. 25, 2051-2052.

Choen, B.K., Pontes, E.J., McDonald, I. \& Rose, N.R. (1977) Immunochemical studies of prostatic acid phosphatase. Cancer Treat. Rep. 61, 201-204.

Crabbe, M.J.C. (1977) The development of a quantitative assay for male infertility from a study of enzymes in human semen. $J$. Reprod. Fert. 51, 73-76.

de Cerezo, J.M.S. \& Cerezo, A.S. (1977) Antigens from human seminal plasma. III. Studies on two new antigens from the trichloroacetic acid soluble fraction. Int. J. Fert. 22, 162-167.

Dravland, E. \& Joshi, M.S. (1981) Sperm coating antigens secreted by the epididymis and seminal vesicle of the rat. Biol. Reprod. 25, 649-658.

Edwards, J.J., Tollaksen, S.L. \& Anderson, N.G. (1981) Proteins of human semen. I. Two-dimensional mapping of human seminal fiuid. Clin. Chem. 27, 1335-1340.

Gleicher, N. (1981) In Reproductive Immunology, vol. 70, pp. 381-461. Alan N. Liss Inc., New York.

Grayhack, J.T., Wendel, E.F., Lee, C. \& Oliver, I. (1977) Analysis of prostatic fluid in prostatic disease. Cancer Treat. Rep. 61, 205-210.

Hein, R.C., Grayhack, J.T. \& Goldberg, E. (1975) Prostatic fluid lactic dehydrogenase isoenzyme pattern of prostatic cancer and hyperplasia. J. Urol. 113, 511-516.

Laemmli, U.K. (1970) Cleavage of structural proteins during the assembly of the head of bacteriophage $T_{4}$. Nature, Lond. 227, 680-685.

Lam, W.K.W., Yam, L.T., Wilbur, H.J., Taft, E. \& ChinYang, L. (1979) Comparison of acid phosphatase isoenzymes of human seminal fluid, prostate, and leukocytes. Clin. Chem. 25, 1285-1289.

Lowry, O.H., Rosebrough, N.J., Farr, H.L. \& Randall, R.J. (1951) Protein measurement with the Folin phenol reagent. J. biol. Chem. 193, 265-275.
Lukac, J. \& Koren, E. (1979) Mechanism of liquefaction of the human ejaculate. II. Role of collagenase-like peptidase and seminal proteinase. J. Reprod. Fert. 56, 501-506.

Mansson, P.E., Sugino, A. \& Harris, S.E. (1981) Use of a cloned double stranded cDNA coding for a major androgen dependent protein in rat seminal vesicle secretion: the effect of testosterone in gene expression. Nucleic Acid Res. 9, 935-946.

McLaren, A. (1964) Immunological control of fertility in female mice. Nature, Lond. 201, 582-585.

Mukherjee, D.C., Agrawal, A.K., Manjunath, R. \& Mukherjee, A.B. (1983) Suppression of epididymal sperm antigenicity in the rabbit by uteroglobin and transglutaminase in vitro. Science, N. Y. 219,989-991.

O'Farrell, P.H. (1975) High resolution two-dimension electrophoresis of protein. J. biol. Chem. 250, 40074021 .

Ostrowski, M.C., Kistler, M.K. \& Kistler, W.S. (1979) Purification and cell-free synthesis of a major protein from rat seminal vesicle secretion. J. biol. Chem. 254, 383-390.

Perwein, E. \& Schill, W.B. (1982a) Microdisc gradient gel electrophoresis of seminal plasma proteins before and after vasectomy and in different split ejaculate fractions. Andrologia 14, 130-134.

Perwein, E. \& Schill, W.B. (1982b) Androgen dependent seminal plasma proteins demonstrated by microdisc gradient polyacrylamide gel electrophoresis. Andrologia 14, 219-222.

Reddy, J.M., Stark, R.A. \& Zaneveld, L.J.D. (1979) A higher molecular weight antifertility factor from human seminal plasma. J. Reprod. Fert. 57, 437-446.

Sutton, J.C. (1979) Further alleles of phosphoglucomutase in human semen detected by isoelectric focusing. J. Forensic. Sci. 24, 189-192.

Tauber, P.F., Zaneveld, L.J.D., Propping, D. \& Schumacher, G.F.B. (1975) Components of human split ejaculates. I. Spermatozoa, fructose, immunoglobulins, albumin, lactoferrin, transferrin and other plasma proteins. J. Reprod. Fert. 43, 249-267.

Vihko, P., Konturri, M. \& Korhonen, I.K. (1978) Purification of human prostatic acid phosphatase by affinity chromatography and isoelectric focusing. Clin. Chem. 24, 466-470.

Witkin, S.S., Higgins, P.J. \& Bendich, A. (1978) Inhibition of viral reverse transcriptase and human sperm DNA polymerase by antisperm antibodies. Clin. exp. Immunol. 33, 244-251.

Received 12 March 1984 